\title{
Nitrogen removal from urban wastewater by activated sludge process operated over the conventional carbon loading rate limit at low temperature
}

\author{
Jean-Marc Choubert ${ }^{1^{*}}$, Yvan Racault ${ }^{1}$, Alain Grasmick ${ }^{2}$, Christian Beck ${ }^{3}$ and Alain Heduit ${ }^{4}$ \\ ${ }^{1}$ CEMAGREF, "Networks, Water Treatment and Water Quality" Research Unit, 50 avenue de Verdun, 33612 CESTAS, FRANCE \\ ${ }^{2}$ Laboratoire GPSA, Université de Montpellier II, CC024, Place Eugène Bataillon, 34095 MONTPELLIER Cedex 05, FRANCE \\ ${ }^{3} E N G E E S$, Laboratoire d'Hydraulique Urbaine, BP 1039-F, 67070 STRASBOURG Cedex, France \\ ${ }^{4}$ CEMAGREF, "Hydrosystems and bioprocesses" Research Unit, Parc de Tourvoie, BP 44,
} 92163 ANTONY Cedex, FRANCE

\begin{abstract}
This study deals with nitrogen removal from urban wastewater employing the activated sludge process at low temperature. It aims at determining the performances and rates of nitrification, and characterising the autotrophic biomass (concentration and kinetic parameters) at $11^{\circ} \mathrm{C}$ and for $\mathrm{F} / \mathrm{M}$ ratios higher than the conventional maximum value of $0.1 \mathrm{~kg}$ $\mathrm{BOD}_{5} \cdot \mathrm{kg} \mathrm{MLVSS}^{-1} \cdot \mathrm{d}^{-1}$ (i.e. SRT around $15 \mathrm{~d}$ ).

To reach this objective, a study of a continuous activated sludge pilot plant operated under controlled conditions was undertaken for five months. Two methods were used:

- A combination of nitrogen mass balance on the continuous reactor and weekly tests in a separate batch reactor

- The use of the Activated Sludge Model No $1\left(\mathrm{ASM}_{1}\right)$ calibrated and validated with 6 intensive sampling test runs in the aeration tank of the pilot plant.

Once it had been demonstrated that it was not possible to predict the nitrogen concentrations with the ASM default values recommended at $10^{\circ} \mathrm{C}$, we modified 4 parameters to correctly simulate the 6 intensive sampling test runs: the autotrophic biomass maximum growth rate values $\left(\mu_{\text {maxi }}=0.22 \mathrm{~d}^{-1}\right.$ with a decay rate value of $\left.b_{A}=0.02 \mathrm{~d}^{-1}\right)$, as well as three of the halfsaturation constants $\left(\mathrm{K}_{\mathrm{NH}}=0.05 \mathrm{mg} \mathrm{NH}_{4}-\mathrm{N}^{\ell^{-1}}, \mathrm{~K}_{\mathrm{OH}}=0.05 \mathrm{mg} \mathrm{O}_{2} \cdot \ell^{-1}\right.$, and $\mathrm{K}_{\mathrm{s}}=30 \mathrm{mg}$ COD$\left.\cdot \ell^{-1}\right)$.

These modifications, implemented on the basis of more accurate predictions of nitrification and denitrification rates in the aeration tank, have reduced the errors of predictions for the main biological variables in the reactor and in the treated water. The sensitivity of the estimated parameter values to the accuracy of the initialisation conditions step has also been studied. It was shown that a mistake of underestimation of the sludge concentration by $6 \%$, compared to the experimental value, has induced the overestimation of the maximum autotrophic growth rate by $7 \%$.
\end{abstract}

Keywords: activated sludge; nitrification; reaction rates; kinetics parameters; modelling wastewater treatment plant

\section{Nomenclature}

$\mathrm{ASM}_{1} \quad$ Activated Sludge Model No 1

$\mathrm{b}_{\mathrm{A}} \quad$ autotrophic biomass decay rate $\left(\mathrm{d}^{-1}\right)$

$\mathrm{B}_{\mathrm{v}}(\mathrm{N}) \quad$ volumetric nitrogen load $\left(\mathrm{mg} \mathrm{N} \cdot \ell^{-1} \cdot \mathrm{d}^{-1}\right)$

$\mathrm{D}_{\text {aer }} \quad$ daily aeration time $\left(\mathrm{h} \cdot \mathrm{d}^{-1}\right)$

$\mathrm{BOD}_{5} \quad$ biological oxygen demand $\left(\mathrm{mg} \mathrm{O}_{2} \cdot \ell^{-1}\right)$

COD chemical oxygen demand $\left(\mathrm{mg} \mathrm{O}_{2} \cdot \ell^{-1}\right)$

DO dissolved oxygen concentration $\left(\mathrm{mg} \mathrm{O}_{2} \cdot \ell^{-1}\right)$

$\mathrm{f}_{\mathrm{AT}} \quad$ fraction of total sludge mass in the aeration tank $(\%)$

$\mathrm{F} / \mathrm{M} \quad$ organic carbon loading rate $\left(\mathrm{kg} \mathrm{BOD} \cdot \mathrm{kg} \operatorname{MLVSS}^{-1} \cdot \mathrm{d}^{-1}\right)$

$\mathrm{K}_{\mathrm{NH}} \quad$ ammonia half-saturation coefficient for autotrophic biomass $\left(\mathrm{mg} \mathrm{N} \cdot \ell^{-1}\right)$

$\mathrm{K}_{\mathrm{OH}} \quad$ oxygen half-saturation coefficient for heterotrophic biomass $\left(\mathrm{mg} \mathrm{O}_{2} \cdot \ell^{-1}\right)$

$\mathrm{K}_{\mathrm{S}} \quad$ readily biodegradable COD half-saturation coefficient $\left(\mathrm{mg} \mathrm{COD} \cdot \ell^{-1}\right)$

* To whom all correspondence should be addressed.

푱 +335578908 00; fax: +335578908 01;

e-mail: iean-marc.choubert@ $@$ cemagref.fi

Received 16 September 2004; accepted in revised form 13 July 2005.
$\mathrm{MX}_{\mathrm{B}, \mathrm{A}}$

mass of autotrophic bacteria in the system (mg COD)

$\left[\mathrm{NH}_{4}-\mathrm{N}\right]_{\mathrm{AT}}$ aeration tank ammonia nitrogen concentration $\left(\mathrm{mg} \mathrm{N} \cdot \ell^{-1}\right)$

$\left[\mathrm{NO}_{\mathrm{x}}-\mathrm{N}\right]_{\mathrm{AT}}$ aeration tank nitrates + nitrites concentration (mg $\left.\mathrm{N} \cdot \ell^{-1}\right)$

$\left[\mathrm{NH}_{4}-\mathrm{N}\right]_{\text {out }}$ output ammonia nitrogen concentration $(\mathrm{mg} \mathrm{N} \cdot \ell-$ 1)

$\left[\mathrm{NO}_{\mathrm{x}}-\mathrm{N}\right]_{\text {out }}$ output nitrates + nitrites nitrogen concentration $\left(\mathrm{mg} \mathrm{N} \cdot \ell^{-1}\right)$

P.E. population equivalent (for $0.15 \mathrm{~m}^{3} \cdot \mathrm{d}^{-1}$ and $60 \mathrm{~g}$ $\left.\mathrm{BOD}_{5} \cdot \mathrm{d}^{-1}\right)$

$\mathrm{rpm} \quad$ rotations per minute $\left(\mathrm{r} \cdot \mathrm{min}^{-1}\right)$

$\mathrm{r}_{\mathrm{v}, \text { max nit }} \quad$ maximum volumetric nitrification rate $\left(\mathrm{mg} \mathrm{NO}_{\mathrm{x}}\right.$ $\left.\mathrm{N} \cdot \ell^{-1} \cdot \mathrm{h}^{-1}\right)$

SE ([C]) sum of absolute values of the difference between simulated and measured concentrations $\left(\mathrm{mg} \mathrm{N} \cdot \ell^{-1}\right.$. point $\left.^{-1}\right)$. $\mathbf{n}=$ Number of points

SRT sludge retention time or sludge age (d)

$\mathrm{S}_{\mathrm{i}} \quad$ soluble inert COD concentration $\left(\mathrm{mg} \mathrm{COD} \cdot \ell^{-1}\right)$

$\mathrm{S}_{\mathrm{s}} \quad$ soluble biodegradable COD concentration $(\mathrm{mg}$ $\left.\mathrm{COD} \cdot \ell^{-1}\right)$

$\mathrm{S}_{\mathrm{ND}} \quad$ soluble organic nitrogen concentration $\left(\mathrm{mg} \mathrm{N} \cdot \ell^{-1}\right)$ 


\begin{tabular}{|c|c|}
\hline TSS & concentration of total suspended solid (mg SS $\left.\cdot \ell^{-1}\right)$ \\
\hline TKN & total Kjeldahl nitrogen $\left(\mathrm{mg} \mathrm{N} \cdot \ell^{-1}\right)$ \\
\hline $\mathrm{V}_{\mathrm{AT}}$ & volume of aeration $\operatorname{tank}(\ell)$ \\
\hline VSS & $\begin{array}{l}\text { concentration of volatile suspended solid (mg } \\
\left.\text { VSS } \ell^{-1}\right)\end{array}$ \\
\hline$X_{B, A}$ & concentration of autotrophic biomass $\left(\mathrm{mg} \mathrm{COD} \cdot \ell^{-1}\right)$ \\
\hline & $\begin{array}{l}\text { concentration of heterotrophic biomass (mg } \\
\left.\text { COD } \ell^{-1}\right)\end{array}$ \\
\hline & particulate inert COD concentration $\left(\mathrm{mg} \mathrm{COD} \cdot \ell^{-1}\right)$ \\
\hline$X_{s}$ & $\begin{array}{l}\text { Slowly biodegradable COD concentration }(\mathrm{mg} \\
\left.\text { COD } \cdot \ell^{-1}\right)\end{array}$ \\
\hline $\mathrm{X}_{\mathrm{ND}}$ & $\begin{array}{l}\text { slowly biodegradable organic nitrogen concentra- } \\
\text { tion }\left(\mathrm{mg} \mathrm{N} \cdot \ell^{-1}\right)\end{array}$ \\
\hline$X_{p}$ & $\begin{array}{l}\text { concentration of inert COD from decay of the bio- } \\
\text { mass }\left(\operatorname{mg~COD} \cdot \ell^{-1}\right)\end{array}$ \\
\hline $\mathrm{Y}_{\mathrm{A}}$ & $\begin{array}{l}\text { yield coefficient of autotrophic biomass } \\
\left(\mathrm{gCOD}_{\text {produced }} \cdot \mathrm{g} \mathrm{N}_{\text {nitrified }}^{-1}\right)\end{array}$ \\
\hline & maximum autotrophic growth rate $\left(\mathrm{d}^{-1}\right)$ \\
\hline & daily mass of nitrified nitrogen $\left(\mathrm{mg} \mathrm{N} \cdot \mathrm{d}^{-1}\right)$ \\
\hline
\end{tabular}

\section{Introduction}

High nitrogen removal efficiency from wastewaters is expected in sensitive areas above a temperature of $12^{\circ} \mathrm{C}$ (European Directive 91/271/EEC, 1991). The French activated sludge treatment plants are thus operated with an intermittent aeration to nitrify and denitrify in the same tank. In order to have an aeration tank of an appropriate size (large enough) to observe the minimum sludge retention time (SRT) at the temperature reached in winter, an $\mathrm{F} / \mathrm{M}$ ratio lower than $0.10 \mathrm{~kg} \mathrm{BOD}_{5} \cdot \mathrm{kgMLVSS}^{-1} \cdot \mathrm{d}^{-1}$ (extended aeration) is recommended (FNDAE, 2002). However, the actual F/M ratio applied to most French activated sludge treatment plants is much lower, and there is a lack of information on nitrogen removal capacities and of rates at low temperature for an $\mathrm{F} / \mathrm{M}$ ratio near the conventional value.

In the literature, the values of the maximum nitrification rate at $10^{\circ} \mathrm{C}$ are over a very wide range: from 1.0 to $4.5 \mathrm{mg} \mathrm{NO}-\mathrm{N} \cdot \mathrm{g}$ MLVSS $^{-1} \mathrm{~h}^{-1}$ (Burica and al., 1996; McCartney and Oleszkiewicz, 1990; Oleszkiewicz and Berquist, 1988; Palis and Irvine, 1985). The difference can be explained by various operating conditions: organic or nitrogen load imposed, COD/TKN or COD/TSS ratios of the influent (Al-Sa'ed, 1988; Thiem and Alkhatib, 1988).

The maximum nitrification rate is proportional to the product of the maximum growth rate $\left(\mu_{\mathrm{A} \text {, maxi }}\right)$ multiplied by the autotrophic biomass concentration $\left(\mathrm{X}_{\mathrm{B}, \mathrm{A}}\right)$. The characteristics of the reaction medium (temperature, alkalinity, and the availability of oxygen and nitrogenous substrate) modulate the growth rate of the autotrophic culture, while the loads and the extractions of sludge applied affect the biomass concentration (Charley et al., 1980). Unfortunately, direct measurements of these parameters are frequently based on:

- Either experiments conducted in a batch reactor over long periods (measuring $\mu_{\mathrm{A} \text {,maxi }}$ ), where the absence of sludge extraction provides very different conditions for the selection of biological species from those prevailing in continuous flow treatment installations, making extrapolation of the results rather risky (Antoniou et al., 1990; Carucci et al., 1999; Spanjers and Vanrolleghem, 1995; Wiley, 1974);

- Or counting techniques to estimate the amount of bacteria (measuring $\mathrm{X}_{\mathrm{B}, \mathrm{A}}$ ). This technique provides a high underestimation of the bacteria (Brion and Billen, 2000; Jensen et al., 1988).
For this reason, indirect determination methods are increasingly used to estimate the maximum growth rate and the concentration of the autotrophic biomass. The results obtained are insensitive to the parameters other than the autotrophic decay rate (Yuan et al., 1999). One of these indirect methods is based on deterministic models comprising equations that describe the growth and decay processes of heterotrophic and autotrophic biomass. The kinetic parameters describing their activity are modified until there is an acceptable fit between numerical forecasts and experimental measurements.

The most widely used tool is the $\mathrm{ASM}_{1}$ (Activated Sludge Model No 1). It has been in widespread use for about 15 years, incorporating the coefficients proposed by Henze (1986) where some parameters are modified to provide more accurate simulated results for each system under consideration (Gujer and Henze, 1991). However, adjustment has often been restricted to the values of the output variables without checking the validity of predicting variables in a reaction system, due to the lack of accurate measurements. This approach is neither able to identify the relevant parameters (Van Veldhuizen et al., 1999) nor completely suitable to understand the biological significance of changing the parameters. In many cases, therefore, the parameters have been more modified than was necessary (Lesouef et al., 1992).

This research particularly targeted evaluating the activity and the characteristics of the autotrophic populations that develop in an activated sludge pilot plant treating urban wastewater at low temperatures $\left(11^{\circ} \mathrm{C}\right)$ operated at a $\mathrm{F} / \mathrm{M}$ ratio close to, or higher than, the conventional $\mathrm{F} / \mathrm{M}$ ratio of $0.10 \mathrm{~kg} \mathrm{BOD} \cdot \mathrm{kg}$ MLVSS $^{-1} \cdot \mathrm{d}^{-1}$. The tests involved a comprehensive experimental monitoring of an activated sludge pilot plant, fed with an urban wastewater, and operating under controlled conditions. Two established methods were used to determine the autotrophic biomass concentration and its maximum growth rate:

- The balance method (Nowak et al., 1994), which consisted of daily calculations of the autotrophic biomass concentration in the continuous reactor on the basis of the loads and sludge extractions applied and determining the maximum growth rate and on the basis of measurements of the maximum nitrification rate in a batch reactor

- Calibrating the $\mathrm{ASM}_{1}$ (Stricker et al., 2003) on the basis of detailed measurements in a continuous flow reactor

\section{Material and methods}

The pilot plant (see Figure 1) combined a $115 \ell$ contact tank (Plexiglas parallelepiped) equipped with a stirrer $\left(80 \mathrm{r} \cdot \mathrm{min}^{-1}\right)$ and a $45 \ell$ clarifier (Plexiglas cylindrical, slope of floor $=40^{\circ}$ ) equipped with a scraper $\left(0.25 \mathrm{r} \cdot \mathrm{min}^{-1}\right)$. Two peristaltic pumps were used to feed the aeration tank $\left(0.6 \ell \cdot \mathrm{min}^{-1}\right.$ for the wastewater and $1.2 \ell \cdot \mathrm{min}^{-1}$ for the sludge recycling loop). An intermittent aeration ( 9 cycles $\cdot \mathrm{d}^{-1}$ of aeration/non-aeration) was supplied with a fine bubbles diffuser (airflow rate $=7 \ell \cdot \mathrm{min}^{-1}$ ) to maintain the dissolved oxygen concentration between 3 and $5 \mathrm{mg} \mathrm{O} \cdot \ell^{-1}$ during aeration phases. Except the removal of sludge which was manually realised once a day, the pilot was controlled by a timer switch. The system was operated for 5 months in a temperature-controlled room to set the temperature of the biomass at $11 \pm 1^{\circ} \mathrm{C}$.

The pilot was fed with a domestic influent from a municipal plant (16,000 P.E.) sampled two or three times per week in the morning, screened at $1.3 \mathrm{~mm}$ and kept in a refrigerated container at $4^{\circ} \mathrm{C}$. Inflow rate variations were applied to the pilot to simulate the inflow variations of full-scale plants located in rural 


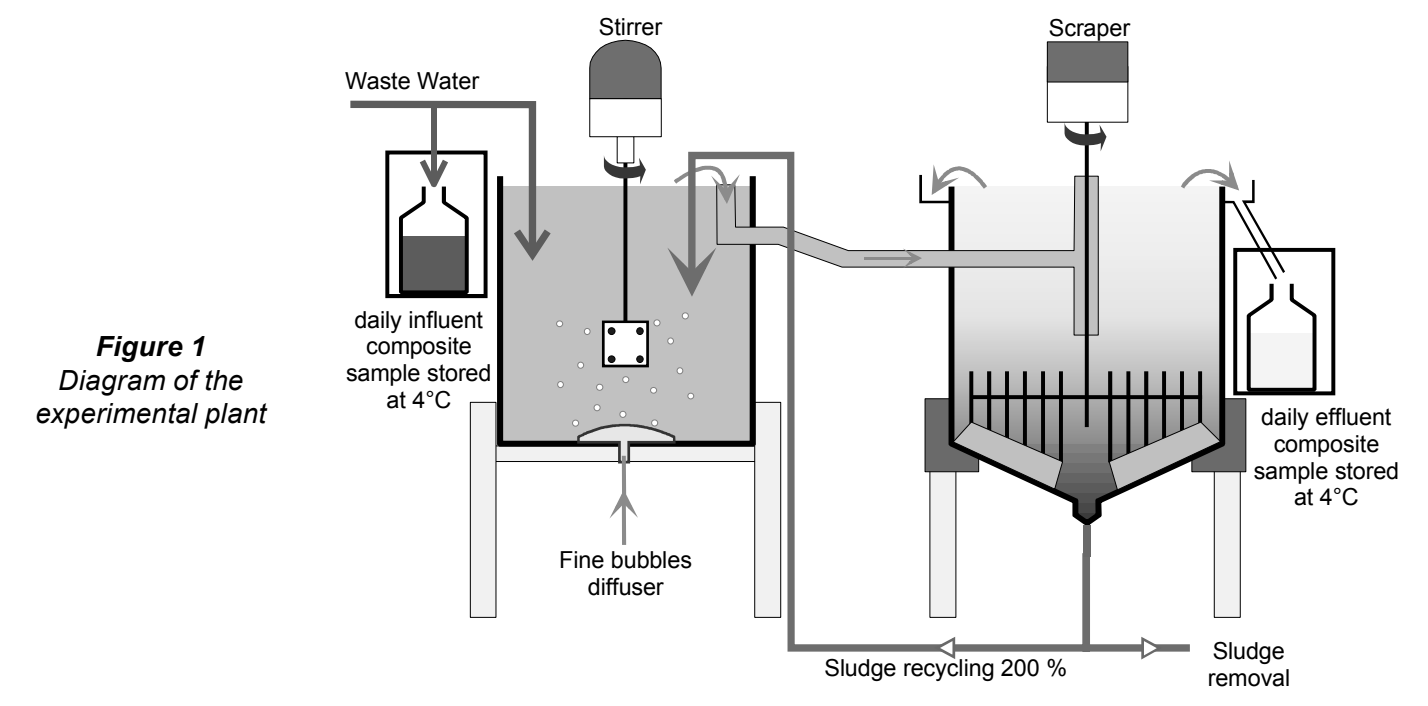

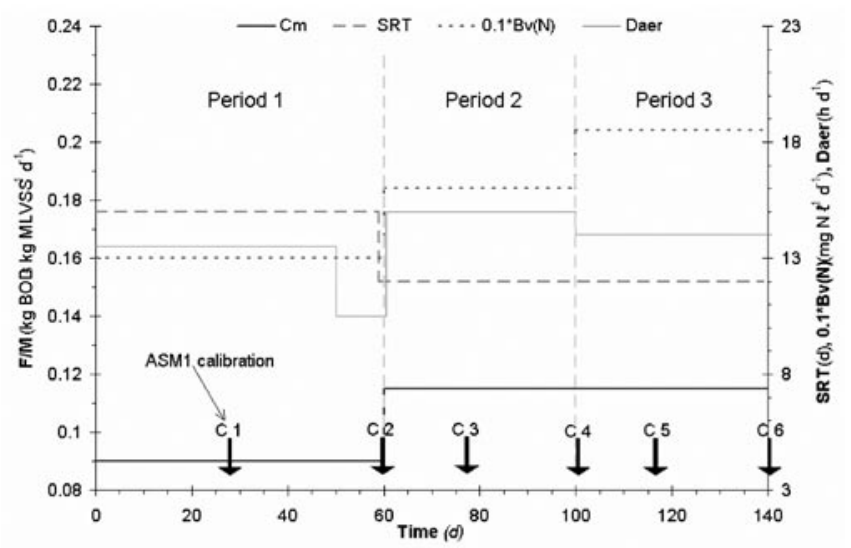

Figure 2

Successive steady state conditions applied to the pilot plant

areas: high morning and evening inflows (peak factor $=2.03$ ), low inflow at night (peak factor $=0.19$ ) with an hourly average inflow rate of $4.17 \%$ of the total daily volume. Daily flow composite samples were collected in the influent and in the treated water. European (NF EN) or international (ISO) standardised analysis techniques were used to measure the following parameters: TKN (NF EN 256-63, mineralisation), $\mathrm{NH}_{4}-\mathrm{N}$ and $\mathrm{NO}_{x}-\mathrm{N}$ (ISO/TC147/2/NG/n 86, spectrophotometry), COD (NF T 90101, mineralisation), $\mathrm{BOD}_{5}$ (NF T 90-103), TSS and MLTSS (NF EN 872, filtration), VSS and MLVSS (not standardised).

The amount of sludge contained in the aeration tank was calculated from MLTSS and MLVSS daily measurements. The sludge mass contained in the clarifier was measured once a week by emptying the content of the clarifier in a separate tank, and measuring MLTSS and MLVSS. The amount of sludge removed from the system (at the bottom of the clarifier) was measured daily from the volumes and the concentration (MLTSS) of sludge removed. The combination of all these values, combined with the inflow data, made it possible to calculate the SRT, and to establish an accurate nitrogen mass balance.

Following a three-week start-up period, the system was run for three successive six-week experimental periods (Periods 1 to 3). Predefined organic and nitrogen loads, and aeration duration were applied in each period (Fig. 2). Organic load was low during the first period, $0.09 \mathrm{~kg} \mathrm{BOD} \cdot \cdot \mathrm{kg} \mathrm{MLVSS}^{-1} \cdot \mathrm{d}^{-1}$, i.e. a sludge age of $15 \mathrm{~d}$, rising to $0.115(\mathrm{SRT}=12 \mathrm{~d})$ in Periods 2 and 3 . The following three levels of volumetric nitrogen load were tested: $160 \mathrm{mg} \mathrm{N} \cdot \ell^{-1} \cdot \mathrm{d}^{-1}$ in Period 1,185 in Period 2, and 220 in Period 3. The last value was obtained by increasing the ammonia nitrogen concentration of the wastewater with chemical ammonium chloride. The aeration duration was in the range 10 to $15 \mathrm{~h} \cdot \mathrm{d}^{-1}$ (see Fig. 2).

Every 3 weeks, at halfway through and at the end of each period, intensive sampling test runs (numbered $\mathrm{C}_{1}$ to $\mathrm{C}_{6}$ ) were carried out. Sludge samples were taken from the aeration tank every $10 \mathrm{~min}$ for $8 \mathrm{~h}$ (i.e. 3 aeration and non-aeration cycles). Once the sludge was centrifuged, the ammonia and nitrate concentrations were analysed.

\section{Balance method}

\section{Calculating the autotrophic biomass concentration in the continuous reactor:}

As the flow rates were known (pollutant loads admitted and mass of sludge produced by the system), Eq. (1) could be used to calculate the quantity of autotrophic biomass $\left(\mathrm{MX}_{\mathrm{B}, \mathrm{A}}\right)$ in the mixed culture (Nowak et al., 1994). The actual autotrophic production was assumed to be proportional to the daily throughput of nitrified nitrogen $\left(\varphi_{\text {Nnit }}\right.$, obtained by the difference between the total nitrogen load applied and the nitrogen assimilated and lost by treated water) less the amount lost through decay $\left(b_{A}\right)$ and that removed by the sludge extraction withdrawal (1/SRT).

$$
\frac{\mathrm{dMX} \mathrm{X}_{\mathrm{B}, \mathrm{A}}}{\mathrm{dt}}(\mathrm{t})=\mathrm{Y}_{\mathrm{A}} \cdot \varphi_{\mathrm{N}_{\text {nit }}}-\left(\mathrm{b}_{\mathrm{A}}+\frac{1}{\mathrm{SRT}}\right) \cdot \mathrm{MX} \mathrm{X}_{\mathrm{B}, \mathrm{A}}(\mathrm{t})
$$

The values for parameters $\mathrm{b}_{\mathrm{A}}$ and $\mathrm{Y}_{\mathrm{A}}$ recommended in the $\mathrm{ASM}_{1}$ are as follows:

- $\mathrm{Y}_{\mathrm{A}}=0.24 \mathrm{~g} \mathrm{COD}_{\text {produced }} \cdot \mathrm{g} \mathrm{N}_{\text {nitrified }}{ }^{-1}$ : a stoichiometric coefficient independent of temperature (Henze et al., 1986; Nowak et al., 1999)

- $\mathrm{b}_{\mathrm{A}}=0.02 \mathrm{~d}^{-1}$ (Dinçer and Kargi, 2000): a kinetic coefficient, difficult to evaluate (Brands et al., 1994). In the absence of a default value at $10^{\circ} \mathrm{C}$, it was calculated from the value at $20^{\circ} \mathrm{C}$ : $0.05 \mathrm{~d}^{-1}$ (Lesouef et al., 1992; Stricker et al., 2003; Suzuki et al., 1999) (which is in the range 0.004 to $0.46 \mathrm{~d}^{-1}$ (Copp and Murphy, 1995; Yuan and Blackall, 2002) by applying the temperature change coefficient (1.103) obtained from the default values for $\mu_{\mathrm{A}, \operatorname{maxi}}\left(0.8\right.$ and $0.3 \mathrm{~d}^{-1}$ at 20 and $10^{\circ} \mathrm{C}$, respectively (Henze et al., 1986). 
Starting with an unknown initial value for the autotrophic biomass concentration $\left(\mathrm{X}_{\mathrm{B}, \mathrm{A}}\right)$, the results from successive balances (Eq. (1)) converged towards a reliable value independent of the initial value after two weeks or more (Nowak et al., 1999).

The autotrophic biomass concentration in the aeration tank $\left(\mathrm{X}_{\mathrm{B}, \mathrm{A}}\right)$, expressed by Eq. (2), was deduced from the volume of the aeration $\tan \mathrm{k}\left(\mathrm{V}_{\mathrm{AT}}\right)$ and the total amount $\left(\mathrm{MX}_{\mathrm{B}, \mathrm{A}}\right)$, taking into account the fraction of the total sludge contained in the intermittently aerated $\operatorname{tank}\left(\mathrm{f}_{\mathrm{AT}}\right)$.

$$
\mathrm{X}_{\mathrm{B}, \mathrm{A}}=\frac{\mathrm{M} \mathrm{X}_{\mathrm{B}, \mathrm{A}}}{\mathrm{V}_{\mathrm{AT}}} \cdot \mathrm{f}_{\mathrm{AT}}
$$

\section{Determining the maximum growth rate in a separate batch}

The maximum nitrification rate $\left(\mathrm{r}_{\mathrm{v} \text {, max nit }}\right)$ was measured every week in a batch reactor maintained at the same temperature as the continuously operated pilot plant. This reactor, filled with $2 \ell$ of sludge taken from the pilot plant, was subjected to the addition of ammonia to reach non-limiting nitrification rate conditions: the initial ammonia nitrogen concentration was above $15 \mathrm{mg} \mathrm{NH}-\mathrm{N} \cdot \ell^{-1}$ and the dissolved oxygen (DO) concentration was always higher than $4 \mathrm{mg} \cdot \ell^{-1}$ (Nowak et al., 1994). Six $25 \mathrm{~m} \ell$ sludge samples were taken over a $1 \mathrm{~h}$ period, immediately filtered, and the filtrate analysed to measure the concentrations of oxidised forms of nitrogen $\left(\mathrm{NO}_{\mathrm{x}}\right)$. The slope of the increase obtained provided the maximum nitrification rate $\left(\mathrm{r}_{\mathrm{V}, \max \text { nit }}\right)$.

Once the autotrophic biomass concentrations in the aeration tank (Eqs.(1) and (2)) and the maximum nitrification rates were known, Eq. (3) was used to calculate the maximum growth rate for this biomass at $11^{\circ} \mathrm{C}$. During the experiment, 21 values of this parameter were obtained.

$$
\mu_{\mathrm{A}, \operatorname{maxi}}=\frac{\mathrm{r}_{\mathrm{v}, \max \text { nit. }} \mathrm{Y}_{\mathrm{A}}}{\mathrm{X}_{\mathrm{B}, \mathrm{A}}}
$$

\section{Calibrating the $\mathrm{ASM}_{1}$}

Calibrating the $\mathrm{ASM}_{1}$ parameters consisted of modifying the kinetic coefficients (e.g. the autotrophic biomass growth rate) until the predictions were as close as possible to reality. The GPS- $X^{\circledast}$ simulation software (produced by Hydromantis, Inc.) was used to simulate the dynamic behaviour of the pilot plant: the $\mathrm{ASM}_{1}$ equations were selected to model the changes of the substrates inside the aeration tank. The separation of treated water and sludge in the clarifier was described by single-dimensional equations applied to ten homogeneous horizontal layers in which no biological reaction occurred (Watson et al., 1994). For the simulations, the COD of the urban wastewater used was characterised in different compartments $\left(\mathrm{S}_{\mathrm{s}}, \mathrm{X}_{\mathrm{s}}, \mathrm{S}_{\mathrm{i}}, \mathrm{X}_{\mathrm{i}}\right)$ on the basis of batch experiments obtained with the protocol proposed by Stricker (2003).

The aeration sequences and inflow rate conditions were described in the model as identical to the experimental. The data recorded during the 3 successive experimental periods and the 6 intensive sampling test runs were used to determine the concentrations and the parameters of the biomass developed in the treatment plant:

\section{Simulations of the 3 by 6 -week experimental periods (initialisation step)}

For each of the 3 periods, the mean operating conditions (load input, sludge concentration, and aeration time) applied to the pilot plant were provided to the model to reproduce the loading rate (COD and nitrogen), the sludge retention time, and the duration of oxygen presence (Brdjanovic et al., 2000; Van Veldhui- zen et al., 1999). Steady-state simulations provided some variables of the reaction medium: biomass $\left(\mathrm{X}_{\mathrm{B}, \mathrm{H}}, \mathrm{X}_{\mathrm{B}, \mathrm{A}}\right)$, particular organic matter $\left(\mathrm{X}_{\mathrm{I}}, \mathrm{X}_{\mathrm{ND}}, \mathrm{X}_{\mathrm{p}}\right)$ and soluble substrate $\left(\mathrm{S}_{\mathrm{I}}, \mathrm{S}_{\mathrm{s}}, \mathrm{S}_{\mathrm{ND}}\right)$, as well as the sludge concentrations in the 10 layers of the clarifier. As their actual values could not be measured, these simulated values were adopted as the initial values for the detailed sampling test runs.

\section{Simulations of the 6 by 8 h periods of detailed moni- toring of the biological reactor}

Once the initial values had been established, the set of detailed sampling was used, taking into account the aeration sequences and hydraulic regime applied to the system. When the simulated concentrations did not match the experimental ones, the kinetic coefficients were modified (e.g. $\mu_{\mathrm{A} \text {, maxi }}$ to obtain more accurate forecasts of mineral nitrogen concentrations). The variables were then reinitialised (previous phase). For each nitrogen species, $\mathrm{C}$, the sum of the absolute difference between the experimental and simulated concentration $\left(\left|[C]_{\text {sim }}^{i}-[C]_{\text {exp }}^{i}\right|\right)$, divided by the number of experimental measurements (n), was calculated to quantify the accuracy of each simulation (Eq. (4)).

$$
\mathrm{SE}([\mathrm{C}])=\frac{1}{n} \cdot \sum_{i \in\{1, n\}}\left|[C]_{\text {sim }}^{i}-[C]_{\exp }^{i}\right|
$$

\section{Results and discussion}

\section{Determining $\mu_{\mathrm{A}, \operatorname{maxi}}$ by the balance method}

Figure 3 shows 21 values calculated by the balance method (Eq. (3)), for maximum growth rate of the autotrophic biomass.

The increase in $\mu_{\mathrm{A} \text {, maxi }}$ observed from the start-up of the installation until day 20 was due to the incorrect value for the initial autotrophic biomass concentration used to solve Eq. (1). After day 20, the choice of the initial concentration does not influence the calculated biomass concentration (Nowak et al., 1994). A value of $0.22 \mathrm{~d}^{-1} \pm 10 \%$ was obtained for $\mu_{\mathrm{A} \text {, maxi }}$ except for day 65 where a very high maximum nitrification rate was obtained (probably bad measurement). The value of $0.22 \mathrm{~d}^{-1}$ is $30 \%$ lower than that proposed by Henze $(1986)$ at $10^{\circ} \mathrm{C}$. Carucci et al. (1999) and Cinar et al. (1998) had already proposed a reduction in the value of this parameter. At $20^{\circ} \mathrm{C}$, Stricker (2003) determined a maximum growth rate of $0.38 \mathrm{~d}^{-1}$, i.e. half the value given by Henze (1986), $0.8 \mathrm{~d}^{-1}$, at the same temperature. Converting Stricker's value $(2003)$ to $10^{\circ} \mathrm{C}$ with a temperature change coefficient of 1.103 (Henze et al., 1986), would give a value of $0.18 \mathrm{~d}^{-1}$, which is $20 \%$ lower than the measured value.

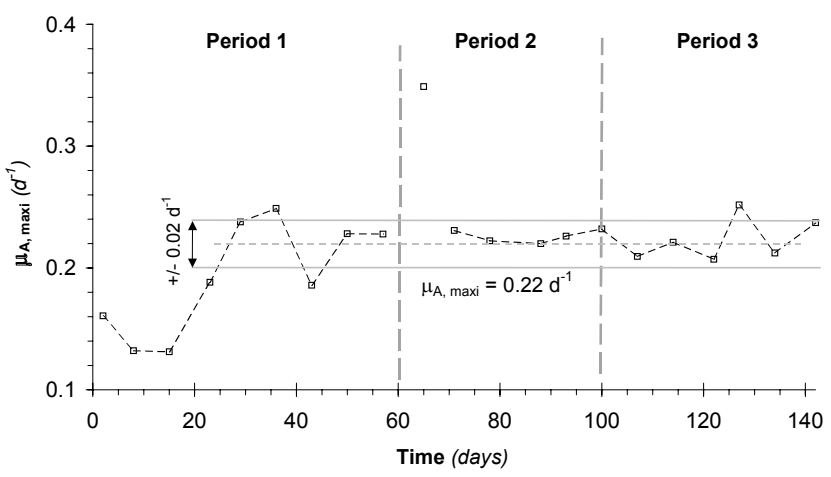

Figure 3

Results of $\mu_{A, \text { maxi }}$ obtained by the balance method 


\begin{tabular}{|c|c|c|c|c|c|}
\hline \multicolumn{6}{|c|}{$\begin{array}{c}\text { TABLE } 1 \\
\text { Observed and simulated values with the default and modified parameters for } \\
\text { test runs } C_{5} \text { (partial nitrification) and } C_{1} \text { (complete nitrification) }\end{array}$} \\
\hline & & & \multicolumn{2}{|c|}{ Simulated value } & \multirow{2}{*}{$\begin{array}{c}\text { Observed } \\
\text { value }\end{array}$} \\
\hline & Variable & Unit & $\begin{array}{c}\text { Default } \\
\text { parameters }\end{array}$ & $\begin{array}{c}\text { Modified } \\
\text { parameters }\end{array}$ & \\
\hline \multirow{6}{*}{ 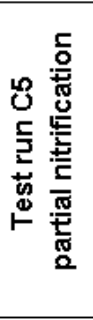 } & $r_{v, \max }$ nit & $m g N \ell^{-1} n^{-1}$ & 15.0 & 7.4 & 7.2 \\
\hline & $x_{B, A}$ & $m g C O D p^{-1}$ & 288 & 180 & \\
\hline & $\mathrm{SE}\left[\mathrm{NH}_{4}-\mathrm{N}\right] \mathrm{AT}$ & $m g N \ell^{-1}$ point $^{-1}$ & 16.4 & 2.4 & \\
\hline & $\mathrm{SE}\left[\mathrm{NO}_{\mathrm{x}}-\mathrm{N}\right] \mathrm{AT}$ & $m g N \ell^{-1}$ point $^{-1}$ & 13.0 & 3.3 & \\
\hline & $\mathrm{SE}\left[\mathrm{NH}_{4}-\mathrm{N}\right] \mathrm{OUT}$ & $m g N \ell^{-1}$ point $^{-1}$ & 8.6 & 1.0 & \\
\hline & $\mathrm{SE}\left[\mathrm{NO}_{\mathrm{x}}-\mathrm{N}\right] \mathrm{OUT}$ & $m g N \ell^{-1}$ point $^{-1}$ & 5.3 & 0.8 & \\
\hline \multirow{6}{*}{ 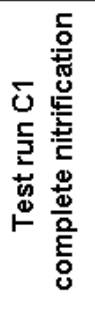 } & $r_{v, \max }$ nit & $m g N \ell^{-1} n^{-1}$ & 13.3 & 9.9 & 10.3 \\
\hline & $x_{B, A}$ & $m g C O D \ell^{-1}$ & 256 & 260 & \\
\hline & $\mathrm{SE}\left[\mathrm{NH}_{4}-\mathrm{N}\right] \mathrm{AT}$ & $m g N \ell^{-1}$ point $^{-1}$ & 1.0 & 0.8 & \\
\hline & $\mathrm{SE}\left[\mathrm{NO}_{\mathrm{x}}-\mathrm{N}\right] \mathrm{AT}$ & $m g N \ell^{-1}$ point $^{-1}$ & 1.1 & 0.5 & \\
\hline & $\mathrm{SE}\left[\mathrm{NH}_{4}-\mathrm{N}\right]$ OUT & $m g N \ell^{-1}$ point $^{-1}$ & 1.3 & 1.5 & \\
\hline & $\mathrm{SE}\left[\mathrm{NO}_{\mathrm{x}}-\mathrm{N}\right] \mathrm{OUT}$ & $m g N \ell^{-1}$ point ${ }^{-1}$ & 0.7 & 0.6 & \\
\hline
\end{tabular}

\section{Calibrating the $\mathrm{ASM}_{1}$ in the biological reactor}

The 6 intensive sampling test runs carried out in the aeration tank were used to calibrate the $\mathrm{ASM}_{1}$ parameters. They may be divided into two categories: Test runs $\mathrm{C}_{1}$ to $\mathrm{C}_{4}$ where nitrification level was high $\left(\left[\mathrm{NH}_{4}-\mathrm{N}\right]_{\text {out }}<10 \mathrm{mg} \mathrm{N} \cdot \ell^{-1}\right)$; test runs $\mathrm{C}_{5}$ and $\mathrm{C}_{6}$ while it was only partial $\left(\left[\mathrm{NH}_{4}-\mathrm{N}\right]_{\text {out }}>10 \mathrm{mg} \mathrm{N} \cdot \ell^{-1}\right)$. As test runs $\mathrm{C}_{1}$ and $\mathrm{C}_{5}$ were representative of their own category, they were used to illustrate the different steps in the calibration of the kinetic parameters of the $\mathrm{ASM}_{1}$ (assuming $\mathrm{Y}_{\mathrm{A}}$ and $\mathrm{b}_{\mathrm{A}}$ values).

\section{Mismatched default parameters}

In cases where nitrification was partial (test run $\mathrm{C}_{5}$ ), the simulations using the set of default parameters provide a maximum nitrification rate $\left(15 \mathrm{mg} \mathrm{NO}-\mathrm{N} \cdot \ell^{-1} \cdot h^{-1}\right)$ and nitrogen concentrations (Table 1 and Figure 4) significantly different from experimental values $\left(7.2 \mathrm{mg} \mathrm{NO}-\mathrm{N} \cdot \ell^{-1} h^{-1}\right)$. This difference was due to an excessively high maximum autotrophic growth rate resulting in an excessive autotrophic biomass concentration. During aeration phases, the simulated rates of ammonia decrease and nitrate increase in the aeration tank were higher than the experimental ones (Fig. 4), while they matched during the anoxic phases.

When the nitrification level was high (test run $C_{1}$ ), the set of default parameters correctly predicted the changes in nitrogen concentrations in the reactor and in the treated water (Fig. 5 and Table 1). However, the simulated maximum nitrification rate $\left(13.3 \mathrm{NO}_{\mathrm{x}}-\mathrm{N} \cdot \ell^{-1} \mathrm{~h}^{-1}\right)$ was $30 \%$ higher than the experimental one (10.3 NO $-\mathrm{N} \cdot \ell^{-1} \mathrm{~h}^{-1}$, Table 1). This difference can be explained in terms of the Monod function $\left(=\left[\mathrm{NH}_{4}-\mathrm{N}\right] /\left(\left[\mathrm{NH}_{4}-\mathrm{N}\right]+\mathrm{K}_{\mathrm{NH}}\right)\right)$ which compensated the maximum growth rate value at low ammonia nitrogen concentrations and resulted in the correct value of the actual growth rate. For an $\mathrm{ASM}_{1}$ calibration at high nitrification levels the measurement of the maximum nitrification rate in a separate batch reactor was required to be relevant, otherwise the overestimation of the maximum growth rate cannot be observed.

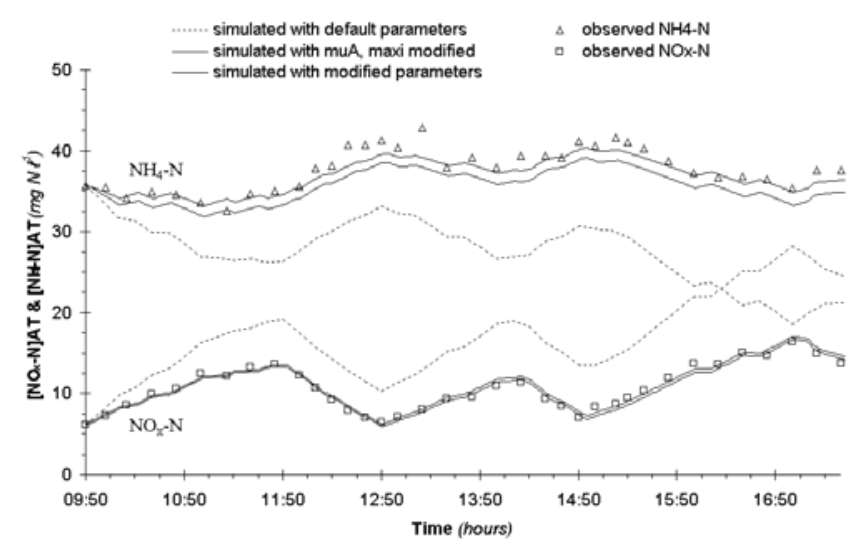

Figure 4

Observed and simulated nitrogen concentrations in the aeration tank (test run $C_{5}$ - partial nitrification) with default, and calibrated parameters ( $\mu_{A, \text { maxi }}$ modified; and 4 modified parameters)

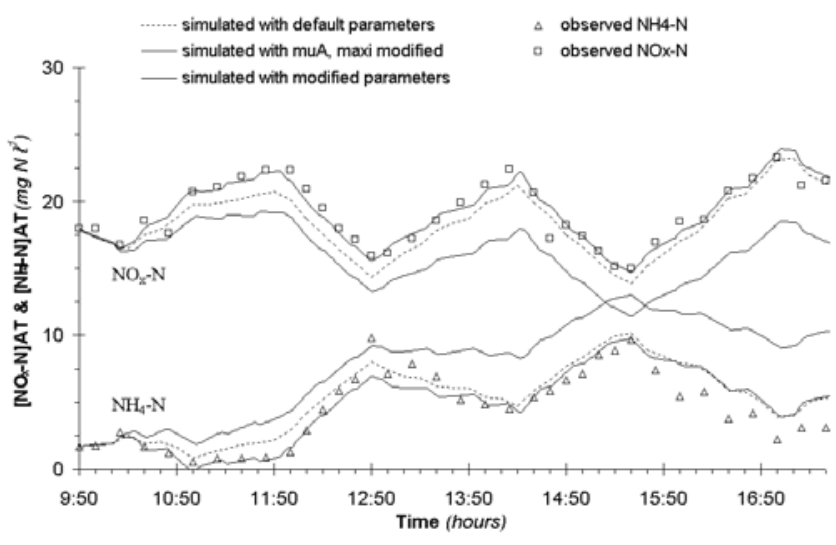

Figure 5

Observed and simulated nitrogen concentrations in the aeration tank (test run $C_{1}-$ high nitrification level) with default, and calibrated parameters ( $\mu_{A, \max i}$ modified; and 4 modified parameters) 
The maximum growth rate value determined by the balance method was introduced in $\mathrm{ASM}_{1}$, thus making the autotrophic population more sensitive to sludge extractions.

\section{Effects of the decrease in maximum growth rate: Need to adjust the half-saturation constants}

When nitrification was only partial (no-limitation by nitrogen concentration - test runs $\mathrm{C}_{5}$ and $\mathrm{C}_{6}$ ), the decrease of the maximum autotrophic growth rate produced a satisfactory match between the simulated and the experimental concentrations of the nitrogen forms in the aeration tank (see Fig. 4). This was due to a lower predicted autotrophic biomass concentration (half of the previous value). It has also resulted in the fit between the simulated and the experimental values for the maximum nitrification rate and the concentrations in the treated water (Table 1).

When a high nitrification level was reached, the modification of the maximum autotrophic growth rate had no effect on the autotrophic biomass concentration (260 instead of $256 \mathrm{mg}$ COD $\left.\ell^{-1}\right)$. The maximum nitrification rate was reduced to $9.9 \mathrm{NO}_{\mathrm{x}}-\mathrm{N} \cdot \ell^{-1} \mathrm{~h}^{-1}$ which, however, agreed with experimental measurements $\left(10.3 \mathrm{NO}-\mathrm{N} \cdot \ell^{-1} \mathrm{~h}^{-1}\right.$, see Table 1$)$.

During the aeration phase, the simulated nitrate and ammonia slopes were lower than those observed in reality were. The simulated ammonium concentrations were no lower than $2.5 \mathrm{mg}$ $\mathrm{N} \cdot \ell^{-1}$ whereas some measurements were close to $1 \mathrm{mg} \mathrm{N} \cdot \ell^{-1}$ (Figure 5, between 9:50 and 11:50).

In order to improve the prediction values for the test run $\mathrm{C}_{1}$, three half-saturation constants, controlling the access to substrates at low concentrations, were modified (Stricker et al., 2003):

- For the nitrification process, the $\mathrm{ASM}_{1}$ default value of the ammonia nitrogen half-saturation constant $\left(\mathrm{K}_{\mathrm{NH}}=1 \mathrm{mg} \mathrm{N} \cdot \ell^{-1}\right)$ seemed too high (Nowak et al., 1994). When it was decreased to $0.05 \mathrm{mg} \mathrm{N} \cdot \ell^{-1}$, the nitrification rate increased due to the increase in the actual nitrification rate at low ammonia concentrations. Decreasing this half-saturation constant gave the autotrophic bacteria easier access to ammonia. Thus low ammonia concentrations can be reached (extended aeration conditions).

- For the denitrification process, the nitrate default halfsaturation constants, $\mathrm{K}_{\mathrm{OH}}=0.2 \mathrm{mg} \mathrm{COD} \cdot \ell^{-1}$ and $\mathrm{K}_{\mathrm{s}}=20 \mathrm{mg}$ COD $\cdot \ell^{-1}$, were modified as indicated by Kristensen (1998) and Stricker et al. (2003). Decreasing the first parameter $\left.\left(\mathrm{K}_{\mathrm{OH}} \text { to } 0.05 \mathrm{mg} \mathrm{O}\right)_{2} \cdot \ell^{-1}\right)$ gave the heterotrophic bacteria easier access to oxygen which corresponds to an easier diffusion of oxygen through the sludge floc (smaller size). It restricted their denitrification rate during the anoxic phase (the aerobic denitrification is unusual in French WWTP) and increased the nitrate production rate during the aeration phase. Increasing the second parameter $\left(\mathrm{K}_{\mathrm{s}}\right.$ to $\left.30 \mathrm{mg} \mathrm{COD} \cdot \ell^{-1}\right)$ made the organic fraction less easy to use in the anoxic phase. It reduced the denitrification rate under low organic carbon conditions and made it possible to adjust the nitrate-simulated concentrations during the anoxic phases.

When ammonia nitrogen elimination was high $\left(\mathrm{C}_{1}\right)$, besides modifying the half-saturation constants, the maximum autotrophic growth rate was necessary to obtain good prediction results. The autotrophic biomass concentration and maximum nitrification rate were predicted with a relative error of $+8 \%$ and $-4 \%$, respectively, compared to the experimental measurements (Table 1).

When only partial nitrification occurred (test run $\mathrm{C}_{5}$ ), the change in the half-saturation constants had little impact on the

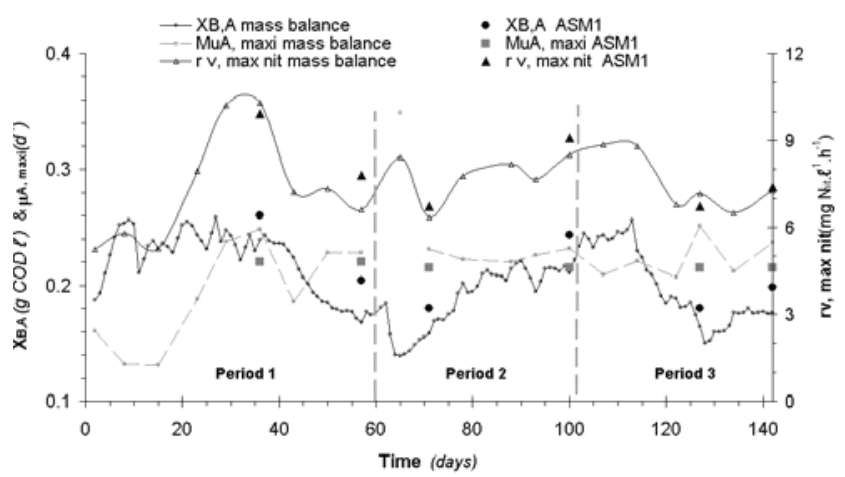

Figure 6

Balance method vs. ASM calibration results for the autotrophic biomass parameters $\left(X_{B, A}, \mu_{A, \text { maxi }}, r_{v, \text { max nit }}\right)$

predictions, particularly because the high substrate concentrations did not restrict the reaction rates. We so obtained, the same set of modified parameters for low and high nitrification levels. This set of parameters also matches the 4 other test runs $\left(\mathrm{C}_{2}, \mathrm{C}_{3}\right.$, $\mathrm{C}_{4}$ and $\mathrm{C}_{6}$ ).

This set of parameters simplifies the number of parameters used: the nitrification reaction rate was not influenced by the ammonia concentration of the reaction media, and the denitrification rate was not influenced by the oxygen concentration.

\section{Accuracy of simulation results using modified parameters}

The relevance of the set of calibrated parameters (obtained for $\mathrm{F} /$ $\mathrm{M} \approx 0.1 \mathrm{~kg} \mathrm{BOD}_{5} \cdot \mathrm{kg} \mathrm{MLVSS}^{-1} \cdot \mathrm{d}^{-1}$ and temperature $=11^{\circ} \mathrm{C}$ ) was assessed by comparing the simulation results for the 6 test runs $\left(\mathrm{C}_{1}\right.$ to $\left.\mathrm{C}_{6}\right)$ in both the biological reactor and in the treated water of the pilot plant.

\section{In the biological reactor}

Figure 6 presents the values for the variables describing the autotrophic biomass in the biological reactor: $\mathrm{X}_{\mathrm{B}, \mathrm{A}}, \mu_{\mathrm{A}, \operatorname{maxi}}$ and $\mathrm{r}_{\mathrm{v}, \max \text { nit }}$.

The values for the maximum nitrification rate and the autotrophic biomass concentration determined by both methods matched throughout the three experimental periods. The simulated values for the maximum nitrification rate were 5 to $10 \%$ lower than the observed ones. This difference results from the underestimation of the simulated autotrophic biomass concentration (by 10 to $20 \%$ ), and from the overestimation of the calibrated maximum growth rate (by +5 to $+15 \%$ ) which lead to conflicting effects.

\section{In the treated water}

Figure 7 presents the mean daily nitrogen concentrations measured in the treated water of the pilot plant for each of the 3 experimental periods. The simulated concentrations obtained during the initialisation step are also specified on the same chart. They should be compared to the experimental values established at the end of each period.

We observed that the mean daily concentrations simulated during initialisation matched the measured values established at the end of each stabilised period. However, the following differences were observed and quantified:

- A difference of -0.8 to $-2.8 \mathrm{mg} \mathrm{NO}_{\mathrm{x}}-\mathrm{N} \cdot \ell^{-1}$ was obtained in the nitrate concentrations. This value is consistent with the results of Funamizu and Takakuwa (1994) who obtained a difference of below $3 \mathrm{mg} \mathrm{NO}-\mathrm{N} \cdot \ell^{-1}$. 


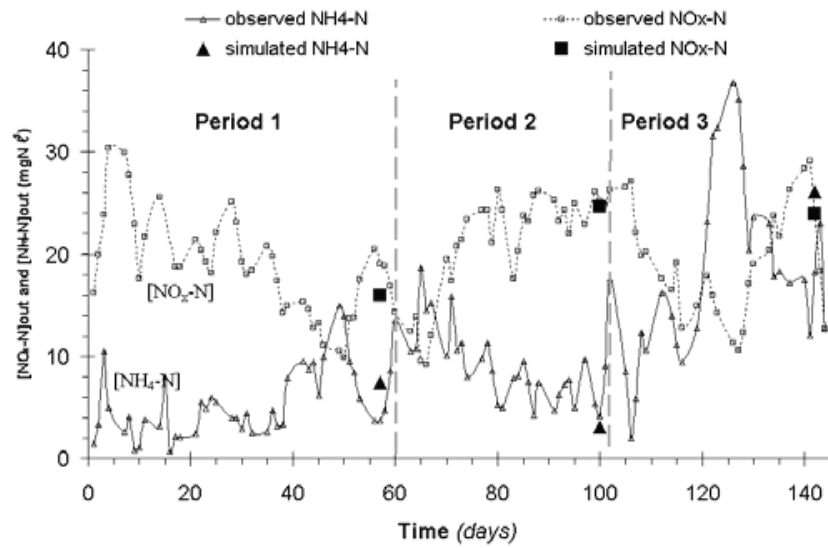

Figure 7

Simulated vs. observed nitrogen concentrations in the treated water for the end of each period (test runs C2, C4 and C6)

- The differences between simulated and actual concentrations of ammonia nitrogen ranged from -6.7 to $+3.5 \mathrm{mg}$ $\mathrm{NH}_{4}-\mathrm{N} \cdot \ell^{-1}$, i.e. -35 to $53 \%$. The fact that these values covered a wider range than those reported in the literature, between 10 to $30 \%$ (Brdjanovic et al., 2000; Carucci et al., 1999; Funamizu and Takakuwa, 1994), was mainly due to the use of a constant inflow rate in the simulations whereas the experimental values were acquired with a variable hourly feed rate.

\section{Accuracy of the calibration results vs. reliability of the initialisation step}

The initialisation step (inflow rate of wastewater, length of aeration periods, and sludge concentration) is used to determine non-measurable variables like heterotrophic and autotrophic biomass concentrations. As these values are essential to calibrate the parameters of $\mathrm{ASM}_{1}$, reproducing the actual operating conditions with care is very important (Brdjanovic et al., 2000; Funamizu and Takakuwa, 1994), otherwise the estimated parameters will not be representative of the actual working conditions (Cinar et al., 1998). The impact of the conclusions drawn to the reliability of the initialisation step has been quantified by testing the sensitivity of the results to the excess sludge withdrawal rate. The Table 2 represents the differences induced by a $10 \%$ over-estimation of the excess sludge withdrawal rate (actual experimental value $7 \ell \cdot \mathrm{d}^{-1}$ ) on the major variables of the system under equivalent aeration conditions.

This mistake had an uneven impact on the following variables:

- A 5\% increase in sludge loading and a $6 \%$ decrease in sludge mass and, thus, concentration. The SRT then decreased by
$13 \%$ due to an increase in the mass of sludge extracted resulting from two factors: the decrease in the sludge concentration and the increase in the withdrawal rate applied. It is particularly important to reproduce the sludge withdrawal rate accurately as it amplifies the error on SRT (Nowak et al., 1999)

- A $7 \%$ decrease in the autotrophic biomass concentration, which, in compensation, led to a $7 \%$ overestimation of the maximum growth rate of the autotrophic biomass

- There was little impact on the concentrations in the treated water: $-4 \%$ for ammonia and $+3 \%$ for nitrates. As the effect on these concentrations is attenuated by a factor 2 , it is preferable to adjust the parameters according to the concentrations in the aeration tank (Kristensen et al., 1998; Stricker et al., 2003)

\section{Conclusion}

The experimental results confirm the feasibility of achieving high nitrogen removal by the activated sludge process operating at $11^{\circ} \mathrm{C}$ and for two $\mathrm{F} / \mathrm{M}$ loading rates close to the conventional load limit, 0.09 and $0.115 \mathrm{~kg} \mathrm{BOD}_{5} \cdot \mathrm{kg} \mathrm{MLVSS}^{-1} \cdot \mathrm{d}^{-1}$. As French plants are mainly operated at $\mathrm{F} / \mathrm{M}=0.07 \mathrm{~kg} \mathrm{BOD}_{5} \cdot \mathrm{kg}$ MLVSS $^{-1} \cdot \mathrm{d}^{-1}$, we can assume that safety coefficients are used, leading to oversized aeration tank volumes.

The balance method has provided a reliable initial estimate of the maximum growth rate of the autotrophic biomass (assuming $b_{A}$ value). Combined with the sampling campaign results (test runs), this made it possible to calibrate some of the halfsaturation constants $\left(\mathrm{K}_{\mathrm{NH}}, \mathrm{K}_{\mathrm{OH}}\right.$, and $\left.\mathrm{K}_{\mathrm{s}}\right)$ of the ASM $\mathrm{A}_{1}$. A single set of modified kinetics parameters has been obtained for the 6 sampling test runs described (as shown in the graphs).

To calibrate the ASM from samplings in the aeration tank (test run), the measurement of the maximum nitrification rate (batch test) is very useful, particularly when a high nitrification level is reached (ammonia concentration $<10 \mathrm{mg} \mathrm{N} \cdot \ell^{-1}$ in the treated water). Otherwise, the overestimation of the maximum growth rate of the autotrophic biomass cannot be detected. In the case of a partial nitrification, the overestimation of the maximum autotrophic growth rate can be established by the difference between the simulated and observed nitrogen concentrations in the reactor. Doing so, 3 half-saturation constants should also be adjusted to reach a satisfactory match between the simulated and the observed concentrations of the nitrogen forms in the aeration tank.

Provided that 4 of the kinetic parameter default values $\left(10^{\circ} \mathrm{C}\right)$ are modified, the nitrogen concentrations and the nitrification/ denitrification rates simulated in the reaction tank with ASM, correspond very closely to the experimental measurements. In the treated water, some differences between the predicted and

\begin{tabular}{|l|l|l|l|l|l|l|l|l|l|}
\hline \multicolumn{7}{|c|}{ TABLE 2} \\
Impact of a mismatch of the excess sludge extraction flow rate on the maximum autotrophic \\
bacteria assessment and on the nitrogen removal performances
\end{tabular}


the experimental values remain, but they were in an acceptable order of magnitude.

Care in using the model, as well as an accurate initialisation step, are vital factors to obtain reliable predictions of nitrogen concentrations and relevant kinetic parameter values as the maximum autotrophic growth rate.

\section{References}

AL-SA'ED R (1988) Investigations on nitrification of ammonia rich wastewater in activated sludge systems. Water Supply 6 235-242.

ANTONIOU P, HAMILTON J, KOOPMAN B, JAIN R, HOLLOWAY B, LYBERATOS G and SVORONOS SA (1990) Effect of temperature and $\mathrm{pH}$ on the effective maximum specific growth rate of nitrifying bacteria. Water Res. 24 (1) 97-101.

BRANDS E, LIEBESKIND M and DOHMANN M (1994) Parameters for dynamic simulation of wastewater treatment plants with highrate and low-rate activated sludge tanks. Water Sci.Technol. 30 (4) 211-214.

BRDJANOVIC D, VAN LOODSDRECHT MCM, VERSTEEG P, HOOIJMANS CM, ALAERTS GJ and HEIJNEN JJ (2000) Modeling COD, $\mathrm{N}$ and $\mathrm{P}$ removal in a full-scale WWTP Haarlem Waarderpolder. Water Res. 34 (3) 846-858.

BRION N and BILLEN G (2000) Wastewater as a source of nitrifying bacteria in river systems : the case of the river Seine downstream from Paris. Water Res. 34 (12) 3213-3221.

BURICA O, STRAZAR M and MAHNE I (1996) Nitrogen removal from wastewater in a pilot plant operated in the recirculation anoxicoxic activated sludge mode. Water Sci. Technol. 33 (12) 255-258.

CARUCCI A, ROLLE E and SMURRA P (1999) Management optimisation of a large wastewater treatment plant. Water Sci. Technol. 39 (4) $129-136$.

CHARLEY RC, HOOPER DG, MCLEE AG (1980) Nitrification kinetics in activated sludge at various temperatures and dissolved oxygen concentrations. Water Res. 14 1387-1396.

CINAR O, DAIGGER GT and GRAEF S (1998) Evaluation of IAWQ Activated Sludge Model No.2 using steady-state data from four full-scale wastewater treatment plants. Water Environ. Res. 70 (6) 1216-1224.

COPP JB and MURPHY KL (1995) Estimation of the active nitrifying biomass in activated sludge. Water Res. 29 (8) 1855-1862.

DINÇER A and KARGI F (2000) Kinetics of sequential nitrification and denitrification processes. Enzyme Microb. Technol. 27 37-42.

EUROPEAN DIRECTIVE 91/271/EEC (1991) Urban wastewater treatment. http://europa.eu.int/comm/environment/water/water-urbanwaste/directiv.html Accessed on 1st July 2005.

FNDAE (2002) Traitement de l'azote dans les stations d'épuration biologique des petites collectivités $96 \mathrm{p}$. accessed at http://www.eau. fndae.fr/documentation/numero_25.htm on 1st July 2005

FUNAMIZU N and TAKAKUWA T (1994) Simulation of the operating conditions of the municipal wastewater treatment plant at low temperatures using a model that includes the IAWPRC activated sludge model. Water Sci Technol. 30 (4) 105-113.

GUJER W and HENZE M (1991) Activated sludge modelling and simulation. Water Sci. Technol. 23 1011-1023.

IAWPRC TASK GROUP ON MATHEMATICAL MODELLING FOR DESIGN AND OPERATION OF BIOLOGICAL WASTEWATER
TREATMENT (1986) Activated Sludge No 1. Henze M, Grady CL, Gujer W, Marais GvR.

JENSEN BK, ERIKSEN T and JORGENSEN E (1988) Determination of active biomass. Water Sci. Technol. 20 (11-12) 213-219.

KRISTENSEN GH, LA COUR JANSEN J and JORGENSEN PE (1998) Batch test procedures as tools for calibration of the activated sludge model - A pilot scale demonstration. Water Sci. Technol. 37 (4-5) 235-242.

LESOUEF A, PAYRAUDEAU M, ROGALLA $\mathrm{F}$ and KLEIBER B (1992) Optimizing nitrogen removal reactor configurations by onsite calibration of the IAWPRC activated sludge model. Water Sci. Technol. 25 (6) 105-123.

McCARTNEY DM and OLESZKIEWICZ JA (1990) Carbon and nutrient removal in a sequencing batch reactor at low temperatures. Environ. Technol. 11 99-112.

NOWAK O, FRANZ A, SVARDAL K, MULLER V and KUHN V (1999) Parameter estimation for activated sludge models with the help of mass balances. Water Sci. Technol. 39 (4) 3-120.

NOWAK O, SCHWEIGHOFER P and SVARDAL K (1994) Nitrification inhibition - A method for the estimation of actual maximum autotrophic growth rates in activated sludge systems. Water Sci. Technol. 30 (6) 9-19.

OLESZKIEWICZ JA and BERQUIST SA (1988) Low temperature nitrogen removal in sequencing batch reactors. Water Res. 22 (9) 1163-1171.

PALIS JC and IRVINE RL (1985) Nitrogen removal in a low-loaded single tank sequencing batch reactor. J. Water Pollut. Control Fed. 57 (1) $82-86$.

SPANJERS H and VANROLLEGHEM P (1995) Respirometry as a tool for rapid characterization of wastewater and activated sludge. Water Sci. Technol. 31 (2) 105-114.

STRICKER AE, LESSARD P, HEDUIT A and CHATELLIER P (2003) Observed and simulated effect of rain events on the behaviour of an activated sludge plant removing nitrogen. J. Environ. Eng. Sci./Rev. Gen. Sci. Env. 2 (6) 429-440.

SUZUKI Y, TAKAHASHI M, HAESSLEIN M and SEYFRIED CF (1999) Development of simulation model for a combined activatedsludge and biofilm process to remove nitrogen and phosphorus. Water Environ. Res. 71 (4) 388-397.

THIEM LT and ALKHATIB EA (1988) In situ adaptation of activated sludge by shock loading to enhance treatment of high ammonia content petrochemical wastewater. J. Water Pollut. Control Fed. 60 (7) 1245-1252.

VAN VELDHUIZEN HM, VAN LOOSDRECHT MCM and HEIJNEN JJ (1999) Modeling phosphorus and nitrogen removal in a full scale activated sludge process. Water Res. 33 (16) 3459-3468.

WILEY J (1974) Measurement of aerobic batch culture maximum specific growth rate and respiration coefficient using a dissolved oxygen probe. Biotechnol Bioeng. XVI 531-538.

YUAN Z and BLACKALL LL (2002) Sludge population optimisation: a new dimension for the control of biological wastewater treatment systems. Water Res. 36 (2) 482-490.

YUAN Z, BOGAERT H, DEVISSCHER M, VANROLLEGHEM P, VAN LOOSDRECHT MCM and VERSTRAETE W (1999) On-line estimation of the maximum specific growth rate of nitrifiers in activated sludge systems. Biotechnol. Bioeng. 65 (3) 265-273.

WATSON B, RUPKE M, TAKACS I and PATRY G (1994) Modelling of full-scale wastewater treatment plants: How detailed should it be? Water Sci. Technol. 30 (2) 141-147. 